\title{
PENGARUH PEMBERIAN EKSTRAK BIJI JARAK PAGAR (Jatropha Curcas L.) TERHADAP MORTALITAS KEONG EMAS (Pomacea sp.) DI RUMAH KACA
}

\author{
Irma Banjarnahor, Lestari Wibowo, Agus M. Hariri \& Rosma Hasibuan \\ Jurusan Agroteknologi, Fakultas Pertanian, Universitas Lampung \\ Jl. Prof. Dr. Soemantri Brojonegoro No. 1 Bandar Lampung 35145 \\ Email: Irma.banjarnahor@ymail.com
}

\begin{abstract}
Keong emas (Pomacea sp.) merupakan salah satu hama pada tanaman padi. Teknik pengendalian yang saat ini banyak dikembangkan adalah dengan memanfaatkan pestisida nabati. Salah satu tumbuhan yang berpotensi sebagai molluskisida nabati adalah jarak pagar (Jatropha curcas L.). Tujuan penelitian ini adalah untuk mengetahui pengaruh ekstrak biji jarak pagar muda dan tua dalam membunuh keong emas dan mengetahui perbedaan toksisitas kedua ekstrak tersebut terhadap keong emas. Penelitian ini dilakukan di rumah kaca Fakultas Pertanian Universitas Lampung pada bulan Mei 6 Oktober 2015. Penelitian disusun dengan rancangan acak kelompok (RAK), dengan 9 perlakuan 4 ulangan. Data hasil penelitian dianalisis dengan sidik ragam dan uji lanjut dengan perbandingan ortogonal kontras. Hasil penelitian menunjukkan bahwa ekstrak biji jarak pagar muda dan tua menyebabkan mortalitas keong emas. Selanjutnya diketahui bahwa ekstrak biji jarak pagar tua toksisitasnya lebih tinggi dibandingkan ekstrak biji jarak pagar muda dalam membunuh keong emas. Aplikasi ekstrak biji jarak pagar tua dengan konsentrasi $15 \mathrm{~g} / \mathrm{l}$ air dan $20 \mathrm{~g} / \mathrm{l}$ air menyebabkan mortalitas keong emas $100 \%$ pada hari ke 3 setelah aplikasi, sedangkan ekstrak biji jarak pagar muda dengan konsentasi tersebut baru dapat mematikan 100\% keong emas uji pada hari ke 7 setelah aplikasi.
\end{abstract}

Kata kunci: ekstrak biji jarak pagar, keong emas, mortalitas

\section{PENDAHULUAN}

Padi (Oryza sativa L.) di Indonesia merupakan tanaman pangan terpenting karena lebih dari setengah penduduk menggantungkan hidupnya pada beras yang dihasilkan tanaman padi (Andoko, 2002). Produksi padi perlu ditingkatkan untuk memenuhi kebutuhan beras nasional. Oleh karena itu setiap faktor yang memengaruhi produksi padi sangat penting diperhatikan (Sugeng, 2011).

Berbagai faktor yang dapat memengaruhi produksi padi meliputi teknik budidaya, ketersediaan unsur hara dan hama penyakit tanaman. Salah satu hama padi adalah keong emas (Pomacea sp.).

Keong emas merupakan hewan Mollusca yang hidup di air tawar. Keong emas bersifat kosmopolitan atau mempunyai daerah penyebaran yang sangat luas. Habitat dari hewan ini adalah rawa, kolam, sawah dan aliran sungai. Keong emas berperan sebagai hama karena dapat menyebabkan kerugian pada tanaman padi muda yang berumur 1-3 minggu setelah tanam. Kerusakan yang ditimbulkan dapat mencapai intensitas 13,2 6 96,5\% (Pitojo, 1996).
Biji jarak pagar dapat dimanfaatkan sebagai molluskisida karena kandungan curcin dan forbol ester yang beracun (Tukimin dkk., 2010). Ekstrak biji jarak pagar juga memiliki potensi sebagai molluskisida terhadap Oncomelania hupensis yang merupakan jenis keong vektor schistosomiasis. Ekstrak biji jarak pagar dengan konsentrasi 32 dan $64 \mathrm{ml} / \mathrm{l}$ air ditemukan keong mati sebesar $100 \%$ pada pengamatan 24 jam setelah aplikasi (Nurwidayati dkk., 2014). Biji jarak pagar yang digunakan adalah biji jarak pagar yang sudah masak penuh atau tua.

Penggunaan ekstrak biji jarak pagar yang masih muda masih jarang digunakan oleh petani-petani di Indonesia untuk mengendalikan hama. Bahkan belum ada dilaporkan bahwa ekstrak biji jarak pagar muda mampu mengendalikan hama.

Biji jarak pagar yang sering digunakan oleh penelitipeneliti di laboratorium maupun di lapangan adalah biji jarak pagar yang sudah masak penuh atau tua. Oleh sebab itu, penelitian ini selain menggunakan biji jarak pagar yang telah tua dicobakan juga biji jarak yang masih muda. Ekstrak biji jarak pagar tua dan muda diharapkan mampu mematikan keong emas. Penelitian ini dilakukan 
untuk mengetahui efektifitas dan perbedaan toksisitas ekstrak biji jarak muda dan tua dalam mematikan keong emas.

\section{BAHAN DAN METODE}

Tempat dan Waktu Penelitian. Penelitian ini dilaksanakan di rumah kaca Fakultas Pertanian Universitas Lampung pada bulan Mei sampai dengan Oktober 2015. Rancangan Percobaan. Penelitian ini menggunakan Rancangan Acak Kelompok (RAK), yang terdiri dari 9 perlakuan dan 4 ulangan. Masingmasing perlakuan tersebut adalah:

$\mathrm{K}=$ tanpa ekstrak biji jarak pagar;

$\mathrm{MJ} 1=5 \mathrm{~g}$ ekstrak biji jarak muda/l air ;

MJ2 = $10 \mathrm{~g}$ ekstrak biji jarak muda/l air;

MJ3 = 15 g ekstrak biji jarak muda/l air;

MJ4 = 20 g ekstrak biji jarak muda/ 1 air;

$\mathrm{TJ} 1=5$ g ekstrak biji jarak tua/l air;

TJ2 $=10$ g ekstrak biji jarak tua/l air;

$\mathrm{TJ} 3=15$ g ekstrak biji jarak tua/l air;

$\mathrm{TJ} 4=20 \mathrm{~g}$ ekstrak biji jarak tua/l air.

Masing-masing perlakuan diulang 4 kali. Setiap satuan percobaan menggunakan 10 ekor keong emas. $\mathrm{K}$ adalah kontrol, $\mathrm{MJ}$ adalah perlakuan dengan ekstrak biji jarak pagar muda dan TJ adalah perlakuan ekstrak biji jarak tua. Penyiapan Keong Emas. Keong emas diambil dari persawahan di Bataranila dengan ukuran yang sama yaitu diameter $\pm 1,6 \mathrm{~cm}$. Keong emas yang sudah dikumpulkan tersebut diadaptasikan dalam ember (volume 4 1) yang diberi kurungan selama 7 hari. Selama dalam proses adaptasi tersebut keong emas diberi makan daun talas dan diganti dengan air yang bersih setiap hari. Pembuatan Ekstrak Biji Jarak Pagar. Biji jarak pagar muda maupun tua yang diambil dari desa Gunung besi, Kecamatan Tanjung Bintang dipetik yang masih muda dan tua. Biji jarak tersebut di kupas untuk diambil bijinya, kemudian ditimbang sesuai dengan perlakuan. Pembuatan ekstrak biji jarak pagar dilakukan dengan menggunakan blender. Pada saat menghaluskan biji jarak pagar dicampurkan dengan $500 \mathrm{ml}$ air.

Aplikasi Ekstrak Biji Jarak Pagar. Keong emas yang sudah di adaptasikan selanjutnya di infestasikan kedalam ember yang berisi air yang ditambahkan dengan ekstrak biji jarak pagar. Kemudian ember tersebut ditutup dengan kain kasa selama pengujian agar keong emas tersebut tidak keluar dalam kurungan ember dan menghindari kemungkinan kegagalan dari faktor lingkungan misalnya gangguan dari manusia dan organisme lain. Selama pengujian keong emas diberi pakan daun talas.

Pengamatan. Peubah yang diamati dalam penelitian ini adalah mortalitas keong emas. Mortalitas dapat dihitung dengan rumus sebagai berikut:

$$
\text { Mortalitas }=\frac{\mathrm{a}}{\mathrm{b}} \times 100 \%
$$

Keterangan:

$\mathrm{a}=$ jumlah keong yang mati

$\mathrm{b}=$ jumlah keong yang di infestasikan.

Pengamatan terhadap mortalitas keong emas dilakukan setiap hari yaitu selama 1-7 hari setelah aplikasi (hsa). Data mortalitas keong emas diolah dengan analisis ragam dan dilanjutkan dengan uji lanjut ortogonal kontras.

\section{HASIL DAN PEMBAHASAN}

Aplikasi ekstrak biji jarak pagar menyebabkan keong emas uji menunjukkan gejala keracunan dan kematian. Keong emas yang keracunan menunjukkan gejala seperti tidak aktif makan, mengeluarkan lendir berwarna putih dan gerakan yang lamban. Sedangkan kematian keong emas ditandai dengan bau yang tidak sedap, tubuh keluar dari cangkang dan terjadi perubahan warna pada keong emas yaitu dari warna kuning terang menjadi kuning pucat kehitaman (Gambar 1).

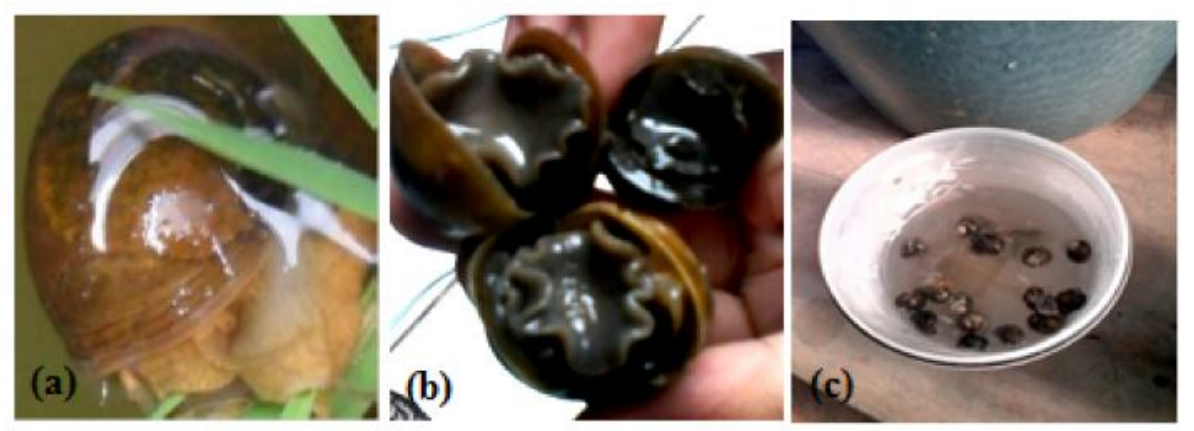

Gambar 1. (a) Gambar keong emas yang masih sehat, (b) keong emas yang sudah mati dengan operculum terbuka, (c) keong emas yang sudah mati mengapung di atas air. 
Pada pengamatan 1-7 hari setelah aplikasi terhadap mortalitas keong emas uji tampak bahwa pemberian perlakuan ekstrak biji jarak muda maupun tua nyata berbeda dengan kontrol. Hal ini menunjukkan bahwa ekstrak biji jarak pagar nyata menimbulkan mortalitas terhadap keong emas uji. Selain itu juga terlihat bahwa antara ekstrak biji jarak pagar muda maupun tua pengaruhnya berbeda dalam menimbulkan mortalitas keong emas uji. Pengaruh ekstrak biji jarak pagar tua menimbulkan mortalitas yang lebih tinggi pada setiap taraf konsentrasi yang dicobakan dibandingkan ekstrak biji jarak muda (Tabel 1).

Perbedaan pengaruh antara taraf konsentrasi terlihat nyata pada konsentrasi tinggi $(15 \mathrm{~g} / \mathrm{l}$ air dan 20 $\mathrm{g} / \mathrm{l}$ air) baik pada perlakuan ekstrak biji jarak pagar muda maupun tua. Pemberian ekstrak biji jarak pagar tua konsentrasi $20 \mathrm{~g} / \mathrm{l}$ air menimbulkan mortalitas yang lebih tinggi $(97,5 \%)$ dan tidak berbeda nyata dengan konsentrasi $15 \mathrm{~g} / \mathrm{l}$ air $(92,5 \%)$ pada 2 hari setelah aplikasi, sedangkan pemberian ekstrak biji jarak muda hanya menimbulkan mortalitas sebesar $12,5 \%$ dan $17,5 \%$ (Gambar 2).
Pada pengamatan terakhir yaitu pada 7 hari setelah aplikasi, tampak bahwa pengaruh ekstrak biji jarak pagar muda konsentrasi $15 \mathrm{~g} /$ lair dan $20 \mathrm{~g} / \mathrm{l}$ air telah mencapai mortalitas $100 \%$. Demikian juga pada perlakuan ekstrak biji jarak tua konsentrasi $10 \mathrm{~g} / \mathrm{l}$ air telah mancapai maksimal yaitu $100 \%$, hal ini tidak berbeda dengan konsentrasi $15 \mathrm{~g} / \mathrm{l}$ air dan $20 \mathrm{~g} / \mathrm{l}$ air mencapai 100\% (Gambar 2).

Mortalitas keong emas menunjukkan bahwa ekstrak biji jarak pagar berpotensi sebagai pestisida nabati untuk mengendalikan keong emas. Berdasarkan hasil perbandingan yang dianalisis, mortalitas keong emas yang diberi perlakuan ekstrak biji jarak pagar nyata lebih tinggi. Hal ini menunjukkan bahwa ekstrak biji jarak pagar mengandung senyawa racun yang bisa mematikan keong emas.

Menurut penelitian Tukimin dkk. (2008), kandungan bahan kimia yang terdapat pada biji jarak dan berhasil dianalisis adalah curcin dan phorbol ester yang dapat berfungsi sebagai racun kontak dan racun perut. Hama yang diujikan pada Tukimin dkk. (2008) adalah hama utama pada kapas Helicoverpa armigera.

Tabel 1. Pengaruh pemberian ekstrak biji jarak pagar terhadap mortalitas keong emas.

\begin{tabular}{lccccccc}
\hline \multirow{2}{*}{ Perbandingan } & \multicolumn{7}{c}{ Pengamatan (hsa) } \\
\cline { 2 - 8 } & 1 & 2 & 3 & 4 & 5 & 6 & 7 \\
\hline $\begin{array}{l}\text { 1. Kontrol vs } \\
\text { MJ1,MJ2,MJ3,MJ4, }\end{array}$ & $16,86^{*}$ & $103,10^{*}$ & $128,73^{*}$ & $130,80^{*}$ & $142,87^{*}$ & $161,26^{*}$ & $268,03^{*}$ \\
TJ1,TJ2,TJ3,TJ4 & & & & & & & \\
2. MJ1 MJ2 MJ3 MJ4 & $27,87^{*}$ & $516,41^{*}$ & $630,90^{*}$ & $377,48^{*}$ & $198,26^{*}$ & $119,57^{*}$ & $344,95^{*}$ \\
$\quad$ vs TJ1 TJ2 TJ3TJ4 & & & & & & & \\
3.MJ1 vs MJ2,MJ3 & $1,49^{\text {tn }}$ & $6,31^{*}$ & $5,95^{*}$ & $14,58^{\text {tn }}$ & $45,16^{*}$ & $37,33^{*}$ & $86,37^{*}$ \\
4.MJ2 vs MJ3 & $4,46^{*}$ & $0,23^{\text {tn }}$ & $0,22^{\text {tn }}$ & $10,94^{\text {tn }}$ & $31,72^{*}$ & $60.22^{*}$ & $163,70^{*}$ \\
5.MJ4 vs TJ1,TJ2 & $32,37^{*}$ & $31,17^{*}$ & $49,67^{*}$ & $5,70^{\text {tn }}$ & $0,05^{\text {tn }}$ & 1,04 & $14,54^{*}$ \\
6.TJ1 vs TJ2 & $0^{\text {tn }}$ & $183,28^{*}$ & 172,81 & $153,79^{*}$ & $102,78^{*}$ & $54,87^{*}$ & $43,61^{*}$ \\
7.TJ2vs TJ3,TJ4 & $103,22^{*}$ & $15,27^{*}$ & $2,65^{\text {tn }}$ & $0^{\text {tn }}$ & $0^{\text {tn }}$ & 0 & $0^{\text {tn }}$ \\
8.TJ3vs TJ4 & $4,46^{*}$ & $0,94^{\text {tn }}$ & $0^{\text {tn }}$ & $0^{\text {tn }}$ & $0^{\text {tn }}$ & 0 & $0^{\text {tn }}$ \\
\hline
\end{tabular}

Keterangan: $*$ = berbeda nyata pada taraf $5 \%(4,26)$, hsa $=$ hari setelah aplikasi, $\mathrm{tn}=$ tidak berbeda nyata pada taraf 5\%, K = Kontrol (tanpa ekstrak biji jarak pagar), MJ1 = Perlakuan pertama (ekstrak biji jarak muda diberi konsentrasi $5 \mathrm{~g} / \mathrm{l}$ air), MJ2 = Perlakuan kedua (ektrak biji jarak muda konsentrasi $10 \mathrm{~g} / \mathrm{l}$ air), MJ3 = Perlakuan ketiga (ekstrak biji jarak muda konsentrasi $15 \mathrm{~g} / \mathrm{l}$ air), MJ4 = Perlakuan keempat (ekstrak biji jarak muda konsentrasi $20 \mathrm{~g} / \mathrm{l}$ air), TJ1 = Perlakuan kelima (ekstrak biji jarak tua konsentrasi $5 \mathrm{~g} / \mathrm{l}$ air), TJ2 = Perlakuan keenam (ekstrak biji jarak tua konsentrasi $10 \mathrm{~g} / \mathrm{l}$ air, TJ3 = Perlakuan ketujuh (ekstrak biji jarak tua konsentrasi $15 \mathrm{~g} / \mathrm{l}$ air), TJ4 = Perlakuan kedelapan (ekstrak biji jarak tua konsentrasi $20 \mathrm{~g} / \mathrm{l}$ air). 


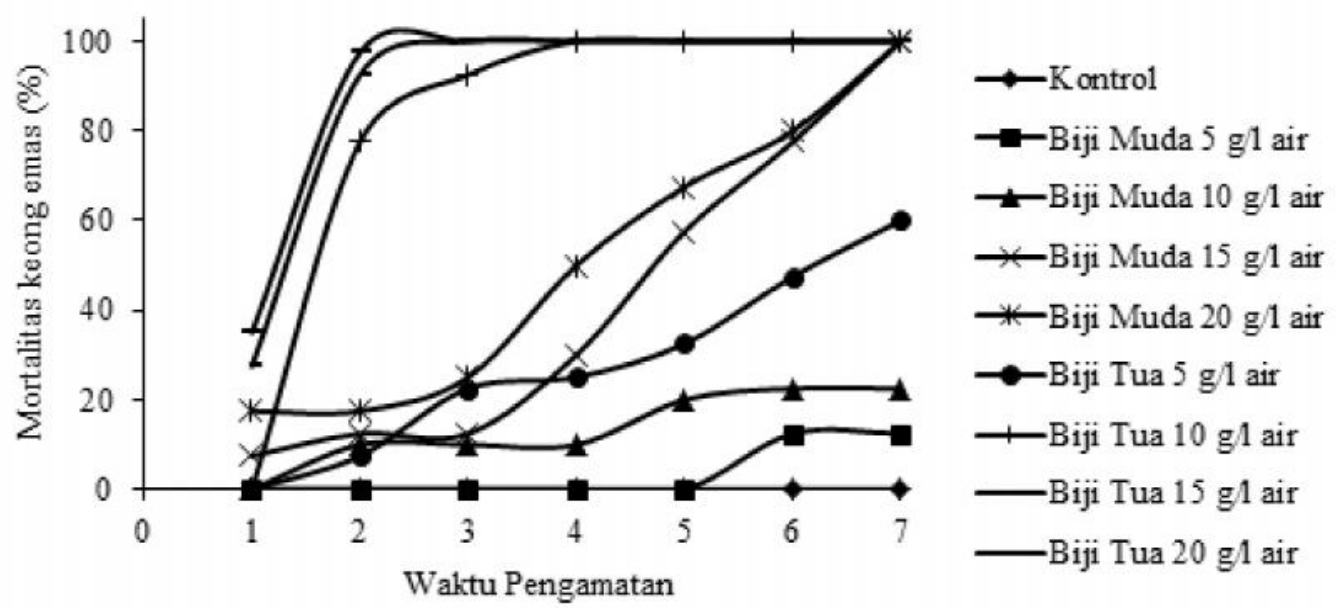

Gambar 2. Mortalitas keong emas pasca aplikasi ekstrak biji jarak pagar.

Phorbolester dan curcin masuk ketubuh serangga uji sebagai racun kontak, racun perut dan bekerja sebagai racun saraf. Dengan konsentrasi $10 \mathrm{ml}$ minyak bungkil biji jarak dan $1 \mathrm{~g}$ detergen per 1 air mampu menyebabkan kematian larva $H$. Armigera sebesar $61 \%$. Selaras dengan hasil penelitian Setiawan dkk. (2012) yang menyatakan bahwa kandungan biji jarak pagar adalah phorbol ester dan curcin. Kandungan biji jarak pagar tersebut masuk kedalam saluran pencernaan hama rayap dan mempengaruhi proses metabolisme. Perlakuan dengan tepung biji jarak pagar tua konsentrasi $20 \mathrm{~g} / 50 \mathrm{~g}$ serbuk gergaji mampu mematikan rayap $100 \%$ pada 3 hari setelah aplikasi.

Berdasarkan perbandingan yang dianalisis, mortalitas keong emas yang diberi perlakuan ekstrak biji jarak tua toksisitasnya lebih tinggi dibandingkan dengan ekstrak biji jarak muda. Pada perlakuan ekstrak biji jarak tua konsentrasi $20 \mathrm{~g} / \mathrm{l}$ air dan $15 \mathrm{~g} / \mathrm{l}$ air, pengamatan 3 hari setelah aplikasi mortalitas keong emas telah mencapai $100 \%$. Sedangkan pada perlakuan ekstrak biji jarak muda konsentrasi $15 \mathrm{~g} / \mathrm{l}$ air dan $20 \mathrm{~g} /$ 1 air mortalitas keong emas mencapai $100 \%$ pada 7 hari setelah aplikasi. Penelitian Nurwidayati dkk. (2014), melaporkan ekstrak biji jarak tua toksisitasnya tinggi terhadap keong vektor schistosomiasis Oncomelania hupensis. Dengan konsentrasi 32 dan $64 \mathrm{ml} / \mathrm{l}$ air ditemukan keong mati sebesar $100 \%$ pada pengamatan 24 jam setelah aplikasi.

Hasil perbandingan mortalitas keong emas pada beberapa konsentrasi ekstrak biji jarak pagar, terlihat pada perlakuan ekstrak biji jarak pagar muda $5 \mathrm{~g} / \mathrm{l}$ air memberikan mortalitas paling rendah. Mortalitas keong emas yang dihasilkan sangat rendah yaitu $12,5 \%$ sampai 7 hari setelah aplikasi. Hal ini disebabkan karena konsentrasi $5 \mathrm{~g} / \mathrm{l}$ air adalah konsentrasi yang terendah dari semua perlakuan. Konsentrasi yang paling rendah membutuhkan waktu yang lebih lama dalam mematikan keong emas. Pernyataan ini didukung oleh penelitian Setiawan (2012), dengan tepung biji jarak pagar $5 \mathrm{~g} / 50$ $\mathrm{g}$ serbuk gergaji memberikan mortalitas terendah pada rayap dari semua perlakuan. Menurut Rusdy (2010), konsentrasi zat racun yang kurang pekat mengakibatkan tidak optimal dalam mengendalikan hama keong mas.

Pada perbandingan yang dianalisis, perlakuan yang diberi ekstrak biji jarak pagar muda maupun tua pada beberapa konsentrasi memberikan mortalitas yang berbeda-beda. Mortalitas keong emas terlihat bahwa semakin tinggi konsentrasi ekstrak biji jarak pagar yang digunakan semakin tinggi pula mortalitas keong emas. Konsentrasi yang paling tinggi ( $20 \mathrm{~g} / \mathrm{l}$ air) pada 2 hari setelah aplikasi ekstrak biji jarak yang telah tua paling cepat mematikan keong uji sebesar 97,5\%. Hasil penelitian ini sesuai dengan pendapat Dewi (2010), bahwa konsentrasi ekstrak yang lebih tinggi maka pengaruh yang ditimbulkan semakin tinggi, di samping itu daya kerja suatu senyawa sangat ditentukan oleh besarnya konsentrasi ekstrak bahan tumbuhan tersebut.

\section{KESIMPULAN}

Ekstrak biji jarak pagar muda dan biji jarak tua menyebabkan mortalitas pada keong emas. Aplikasi ekstrak biji jarak muda dengan konsentrasi $15 \mathrm{~g} / \mathrm{l}$ air dan $20 \mathrm{~g} / \mathrm{l}$ air menyebabkan mortalitas keong emas $100 \%$ pada pengamatan 7 hari setelah aplikasi. Sedangkan aplikasi ekstrak biji jarak pagar tua lebih cepat menimbulkan mortalitas keong emas $100 \%$ yaitu pada 3 hari setelah aplikasi.

$\begin{array}{lllll}3 & 4 & 5 & 6 & 7\end{array}$




\section{DAFTAR PUSTAKA}

Andoko, A. 2002. Budidaya Padi Secara Organik. Penebar Swadaya. Jakarta. $96 \mathrm{hlm}$.

Dewi, R. S. 2010. Keefektifan ekstrak tiga jenis tumbuhan terhadap Paracoccus marginatus dan Tetranychus sp. pada tanaman jarak pagar (Jatrophacurcas L). Tesis. Institut Pertanian Bogor. Bogor.

Nurwidayati, A., N. Veridiana, Octaviani, dan Yudith. 2014. Efektivitas Ekstrak Biji Jarak Merah (Jatropha gossypiifolia), Jarak Pagar (J. curcas) dan Jarak Kastor (Riccinus communis) Famili Euphorbiaceae Terhadap Hospes Perantara Schistosomiasis, Keong Oncomelania hupensis Lindoensis. Jurnal Balaba. 10(1): 9-14.

Pitojo, S. 1996. Petunjuk Pengendalian dan Pemanfaatan Keong Emas. Trubus Agrowijaya. Ungaran. $106 \mathrm{hlm}$.

Rusdy, A. 2010. Pengaruh Pemberian Ekstrak Bawang Putih Terhadap Mortalitas Keong Mas. Jurnal Floratek. 2(5): 172-180.
Setiawan, R., H. Loah dan R. Rustan. 2012. Pemberian Berbagai Konsentrasi Tepung Biji Jarak Pagar (Jatropha curcas L.) untuk Mengendalikan Hama Rayap Coptotermes curvignathus Holmgren (Isoptera: Rhinotermitidae) di Laboratorium. Jurnal IlmuIlmu Pertanian. 4(2): 144-160.

Sugeng, H. 2001. Bercocok Tanam Padi. Aneka Ilmu. Semarang. $178 \mathrm{hlm}$.

Tukimin, D. Soetopo dan E. Karmawati. 2010. Pengaruh minyak jarak pagar (Jatropha curcas L.) terhadap mortalitas, berat pupa, dan penularan hama jarak kepyar. Jurnal Littri. 16(4): 159-164.

Tukimin, D. Soetopo, dan Soebandi. 2008. Toksisitas minyak tiga aksesi jarak pagar (Jatropha curcas L.) terhadap Helicoverpa armigera Hubner. Prosiding Loka Karya Nasional Jarak Pagar IV, 16 April 2008. Puslitbangbun Bogor. $4 \mathrm{hlm}$.

Yunidawati, W., D. Bakti, dan B. S. J. Damanik. 2011. Penggunaan Ekstrak Biji Pinang untuk Mengendalikan Hama Keong Mas (Pomacea canaliculata Lamarck) pada Tanaman Padi. Jurnal Ilmu Pertanian Kultivar. 5(2): 1-8. 